\title{
CMTD（曲がり多重チューブ）を用いた肝穿刺システムの開発と 胆管への穿刺のための基礎的検討
}

Development of the needle insertion system to the liver using CMTD(Curved Multi-Tube Device)

and Fundamental examination for puncture to the bile duct

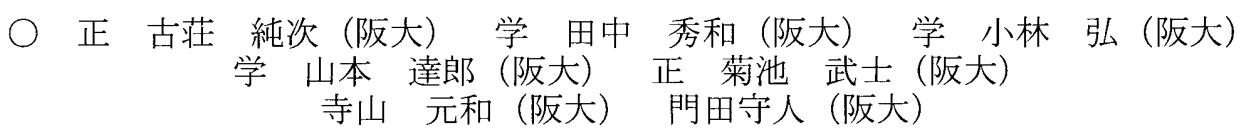

Junji FURUSHO, Osaka Univ., furusho@mech.eng.osaka-u.ac.jp

Hidekazu TANAKA, Osaka Univ., Hiroshi KOBAYASHI, Osaka Univ., Tatsuro YAMAMOTO, Osaka Univ.,

Takehito KIKUCHI, Osaka Univ., Motokazu TERAYAMA, Osaka Univ., Morito MONDEN, Osaka Univ.

The authors developed CMTD (Curved Multi-Tube Device) and studied the system which performed puncture to the liver by machine control.CMTD, which consists of a straight outer needle and a curved inner needle, can revise the error that occurred during puncture. By the system, we detect the puncture angle of the needle during puncture by clicking points of needle on the ultrasound image as a sensor with somascope. We supposed PTCD (percutaneous transhepatic cholangiodrainage) as an environment, and we tested puncture to the silicon tube which simulated a bile duct using this system and studied the effectiveness of this.

Key Words: Curved Multi-Tube Device, PTCD, needle insertion system, ultrasound image, path-error correction

\section{1 肝穿刺}

\section{1. 緒言}

肝穿刺とは肝臓に針を刺す行為で，主に肝臓における腫瘍 の治療や組織検査の際に行われる, 重要で頻度の高い手技で ある. PTCD（経皮経肝胆管ドレナージ）では腫瘍（胆管癌） により閉塞した胆管中の胆汁を外一排出するためにチューブ を挿入する際に，穿刺が行われる。

合併症としては出血・胆汁漏などがあり，重大な事態にな ることもある．合併症が起こる理由はさまざまだが，針が目 標物に正確に到達せず，周囲の臟器を損傷することが大きな 理由の一つである，その原因としては，目標物が小さく体表 から離れていること, 針の進入による組織の変形で目標点が 移動すること, 針が細いために皮膚や臓器を通過する際に変 形することなどが考えられる[1].

\subsection{CMTD（曲がり多重チューブ）}

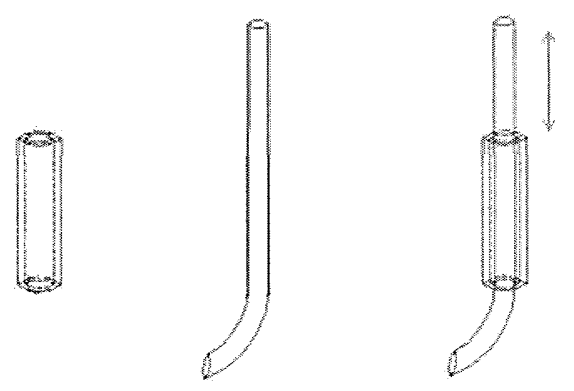
(a) Straight
(b) Curved
outer needle
inner needle
(c) Combined needle

Fig. 1 Concept of CMTD

CMTD (曲がり多重チューブ) は，まっすぐな外針と，曲が り部を有する内針からなる. 図.1 のように，内針と外針を相
対的に動かすことで，「Stragiht Phase」と「Curved Phase」の $2 つ$ 状態を再現でき, 直線状と円弧状の 2 つ経路を進むこ とができる[2].

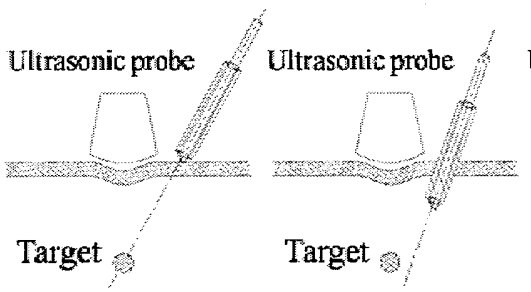

(a) (b)

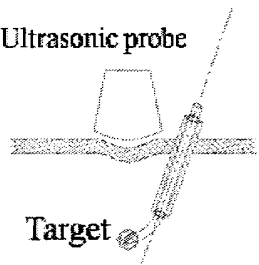

(c)
Fig. 2 The procedure of punctures using a CMTD

外針の穿刺角度が目標点とずれた場合，外針を固定して内 針のみを穿刺することで，実質臓器を傷つけることなく目標 を穿刺することができる（図.2）.

\section{3 研究目的}

この穿刺行為を機械制御により安全，かつ正確に行うこと ができれば，患者にとっても医師にとっても恩恵である.

本研究では，穿刺中に生じた誤差を実質臓器内で補正する ことのできる多重曲がり針(CMTD)を用いて，穿刺システム を構築することを目的とする。ここでは PTCD を想定し, 豚 肝藏中で，模擬された胆管(直径約 $5[\mathrm{~mm}]$ )に穿刺を行うこと を目標とする.

\section{2. 装置概要}

肝穿刺システムは CMTD を制御する穿刺装置と, 超音波プ ローブを制御するプローブ走査装置からなる.

\section{1 穿刺装眞}


穿刺装置（図.3）は，CMTD の穿刺角度制御および，外針 直動，内針直動，内針回転の 4 自由度を持つ[3]。

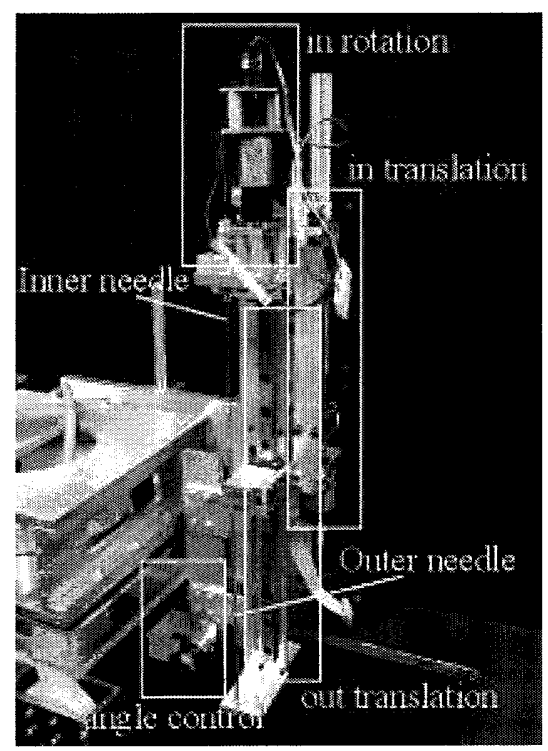

Fig. 3 Needle insertion system

\section{2 プローブ走查装置}

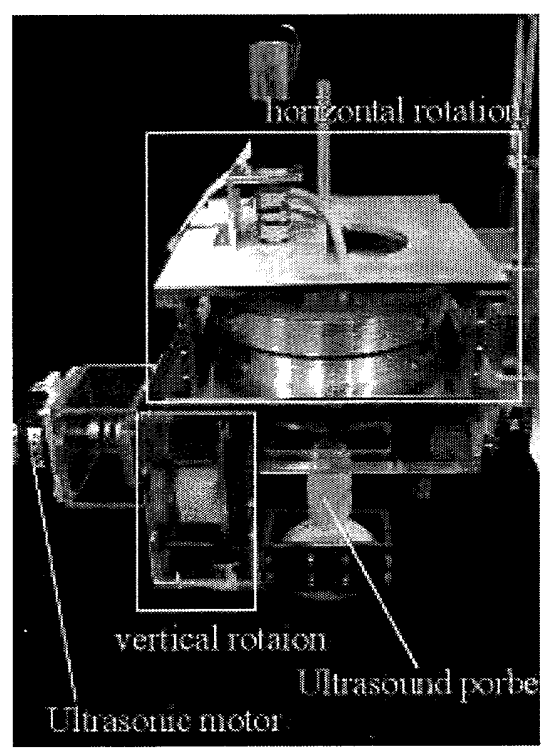

Fig. 4 Probe scanning system

超音波プローブを穿刺装置に対して固定した場合，針を実 質臓器に刺したときに，変形によって針が超音波プローブに 対して奥行き方向に曲がると, 超音波画像から針が見えなく なってしまう.

そこで，プローブを可動式にして，針を探索できるように， プローブ走査装置(図.4)を設計した。 プローブ走査装置は 2 自由度からなる. 図.5 に示す動作イメージ図において, 矢印 $\mathrm{A}$ はプローブの水平回転, 矢印 B はプローブの首振りを表 す.

首振り走査のアクチュエータとしては，非通電時にセルフ ロックによりプローブが固定でき，また高トルクであること から，超音波モータを採用した。

プローブの首振りは，医師が実際にプローブを振るときの 動きを考えて，プローブ先端が接している体表面を回転軸と
してプローブを回転させる方式をとっている.

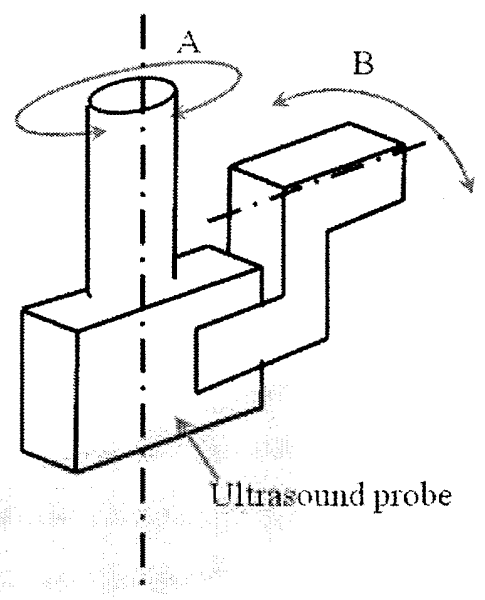

Fig. 5 Concept of probe scanning

\section{3. 針の検出方法}

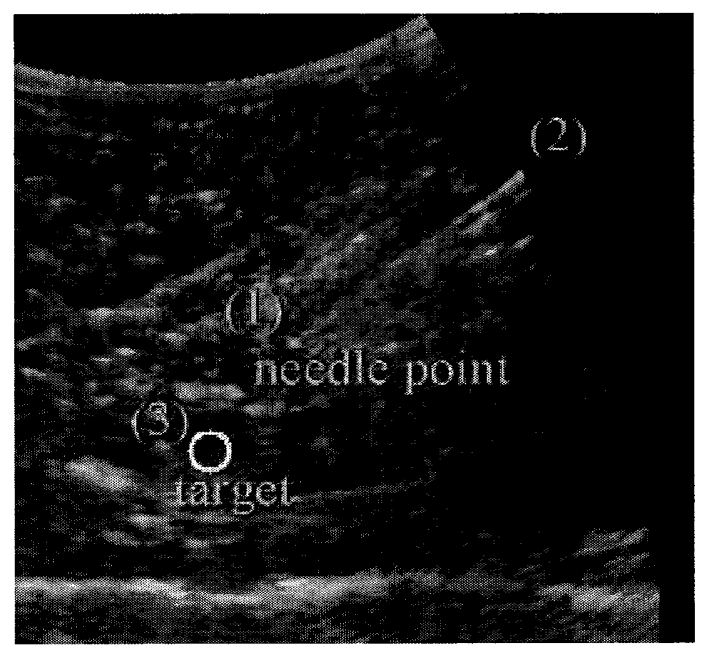

Fig. 6 needle detection by mouse click

実質臓器に対して穿刺を行うと，針は変形する。これに対 してCMTDを用いて誤差補正を行うには，針の位置と姿勢を 正確に知る必要がある。そのためには，針を針先を始点とす る半直線として検出しなければならない。

ところが超音波画像上では肝臟組織の輝度が高いために， 針と画像は見分けづらい。また，対象となる肝臓には個体差 もあるので，最適なパラメー夕は対象ごとに異なると考えら れる。これらから，八フ変換などの画像処理を用いて線分を 検出するのは困難を極める.

そこで，術者が直接，超音波画像上で針の位置を指定する 方法（以下，「点指定」と呼ぶ）を採用する。針を半直線と して検出するには，穿刺角度と針先座標がわかればいい，そ こで，外針穿刺中に一度針を止め，針先と針の別の点もう 1 点をマウスで指定して，穿刺角度を計算する．その際に，穿 刺に伴って移動した目標点を再度指定することで，ある程度 目標点を追従できるようになっている (図. 6 の(1)〜(3)の順に 
指定する）.

\section{4. 穿刺アルゴリズム}

以下に，本研究で用いられた穿刺シスデムのアルゴリズム を示す。

1. 目標点を超音波画像上でマウスクリックして指定する.

2. 外針のみで穿刺可能な目標軌道が計算され，穿刺が開始 される(図.2(a)）。

3．ある程度進んだところで外針が停止する（図．2(b)）。

もし針が見えなければ，キーボード操作によってプロー ブを操作して針を探索する.

4. 超音波画像上で, 針先と針の別の点も51点を指定し,

目標点をもう 1 度指定する。

5. 針先の位置と方向から，穿刺軌道が再計算される.

6. 穿刺を再開し，穿刺角度が目標からずれていれば内針を 用いて誤差補正し，穿刺を完了する（図.2(c)）.

\section{5. 穿刺実験}

\section{1 実験概要}

はじめは，豚の肝臓内の胆管を対象とした実験を考えてい た。しかし，切り取られた肝臟内の胆管では，当然，胆汁は 流れておらず，管が潰れた状態であるために，超音波画像中 で肝臓内の胆管を見わけることができなかった，そこで，豚 肝臓中にプローブ平面と垂直に貫通穴を開け，胆管を模擬し たシリコンチューブを通して実験を行った.

胆管の弾性率は個体差があるだけでなく，1 つの個体中に おいても時空間的に均一ではない。ここでは弾性率の高いも のほど刺しづらいという仮定に立ち，胆管の考えうる最大の 弾性率（2.4〜2.7[MPa]程度）を参考に，シリコンチューブを 選んだ。実際に穿刺の対象となる胆管は，この弾性率よりも 柔らかい場合がほとんどである。

用いたチューブは，PTCDの対象となる胆管の大きさが最 大 $5[\mathrm{~mm}]$ 程度であるので, 内径 $2[\mathrm{~mm}], 6[\mathrm{~mm}]$, および比較 実験として $10[\mathrm{~mm}]$ を用いた。

用いた針の仕様は，外針 $(\varphi 2.41 \times \varphi 1.99[\mathrm{~mm}])$ ，内針 $(\varphi 0.81 \times \varphi 1.51[\mathrm{~mm}])$ である. 針が思ったほど変形せず，超音 波画像上で目で見て針先を十分確認できたので，この実験で はプローブ走查装置は使わなかった.

\section{2 実験結果}

表 1 に，目標の大きさごとの穿刺成功率を示す．なお穿刺 の可否は

- $\bigcirc($ 穿刺成功，針が刺さった，チューブに穴が開い たか否かで判定 $)$

- $\triangle$ (穿刺失敗，針が当たったが刺さらなかった，チ ューブに傷がついたか否かで判定

- $\times($ 穿刺失敗，針が外れた，上記以外の場合）

で判断するものとする
Table. 1 The puncture success rate

\begin{tabular}{|c|c|c|c|}
\hline 目標内径[mm] & $\bigcirc \bigcirc \bigcirc$ & $\bigcirc+\triangle$ & $\times \times \times$ \\
\hline $2[\mathrm{~mm}]$ & 10 & 40 & 60 \\
\hline $6[\mathrm{~mm}]$ & 20 & 80 & 20 \\
\hline $10[\mathrm{~mm}]$ & 60 & 100 & 0 \\
\hline
\end{tabular}

表 1 からわかるように，穿刺成功率は目標が大きくなるほ ど上がっている． $\triangle$ 場合は，チューブの硬さが原因で針が 刺さらなかった場合であり，実際の胆管であれば刺さってい た可能性もある。ただし，実際の手技においては，手技の成 否は臟器の損傷の大きさや，合併症の有無などからはかられ るべきであり，穿刺の可否とは判断基準が異なることに注意 しなければならない。

穿刺失敗の原因としては，目標の再指定後の目標点の移動 や，点指定の際の指定䛊差などが考えられる．誤差伝播より， 目標が小さいときほど，許容䛊差が小さくなるため，穿刺に 失敗する可能性が大きくなる。表 1 の結果もそれを支持して いると言える。

\section{6. 結言}

肝臓内で胆管を模擬した環境で穿刺実験を行い，本 システムが有効に動いていることが確かめられた。ま た，肝臓はもつとも術中に変形しやすい臓器の一つと 言われるが，実際に肝臓への穿刺による針の変形が実 験によって明らかになった。その上で，針の変形を補 正するCMTDおよび点指定システムの有用性が示され たと言える。

今後の課題としては,

・ ある程度の硬さをもつ対象でも容易く刺せるように 針先端形状を検討寸る。

- 内針穿刺期間中の目標移動に対する対策を検討す る.

- より実際の手技に近い環境を模擬しての穿刺実験を 行う.

などがあげられる。

\section{文 献}

[1] Motokazu Terayama, Junji Furusho, Morito Monden, "Curved multi-tube device for path-error correction in a needle-insertion system,"THE INTERNATIONAL JOURNAL OF MEDICAL ROBOTICS AND COMPUTER ASSISTED SURGERY Int J Med Robotics Comput Assist Surg 2007; 3: pp. 125-134.

[2] J.Furusho, T.Katsuragi, T.Kikuchi, T.Suzuki. "International Journal of Computer Assisted Radiology and Surgery Volume 1. Supplement 1. June 2006". pp. 223-226

[3] 古荘純次，寺山元和，田中秀和，葛城孝哉，菊池武士，門田守 人.”曲がり多重チューブシステム (CMTS) を用いた肝穿刺シ ステムの研究開発”, 第 24 回日本ロボット学会学術講演 会, 2006 